\title{
TRADUCCIONS I TRANSMISSIÓ \\ MANUSCRITA: EL PROJECTE «TRANSLAT»
}

\author{
Lluís Cabré \\ Montserrat Ferrer \\ Josep Pujol \\ Universitat Autònoma de Barcelona
}

Lluis.Cabre@uab.cat, montse.ferrersa@gmail.com, Josep.Pujol@uab.cat

Nota Preliminar: El projecte Translat es desenvolupa dins el marc del projecte coordinat "Corpus Digital de Textos Catalans Medievals" (Coditecam), que ha tingut tres fases: 2006-2008, 2009-20II (FFI 2008-05556-Co3) i 20I2-2014 (FFI2OII27844-C03-03). S’han alternat en la direcció Lluís Cabré (2009-20II) i Josep Pujol (2006-2008 i 20I2-20I4), i la coordinació ha anat a càrrec de Montserrat Ferrer (UAB). El projecte compta amb un consell assessor i ha comptat també amb la col.laboració d'investigadors externs al projecte (Stefano M. Cingolani, 2009).

Les traduccions al català medieval no són un camp d'estudi recent. Des dels seus orígens al segle XIx, la historiografia literària catalana ha vist en les traduccions un instrument essencial per a la reconstrucció de la cultura literària del passat: en són emblemàtics els treballs fundacionals d'Antoni Rubió i Lluch, des de El Renacimiento Clásico en la Literatura Catalana (I889) fins als dos volums dels Documents per l'Història de la Cultura Catalana Mig-eval (I908-192I), encara ara punt de referència obligat per al seguiment de l'origen i la difusió de moltes traduccions antigues. D'aleshores ençà, l'edició i l'estudi de les traduccions s'ha transformat substancialment per la creixent atenció dispensada a la transmissió manuscrita de les obres originals, que ens ha ensenyat a valorar la complexitat de la transmissió dels textos traduïts — sovint amb intervenció de diverses llengües_ i a explicar-nos les solucions i els mètodes dels traductors atenent a les pràctiques de lectura i comentari de l'escola medieval. Aquest procés d'afinació del coneixement de les traduccions antigues ha anat acompanyat de sistematitzacions històriques i catàlegs de les traduccions medievals en les diverses llengües romàniques i de l'interès per àrees no estrictament literàries, d'on deriven, per exemple, els grans projectes de catalogació i edició de traduccions bíbliques o l'estudi sistemàtic de les traduccions de textos científics. 
El Grup de Literatura Catalana Medieval del Departament de Filologia Catalana de la UAB treballa des de 2006 en un projecte de recerca finançat que, sota el nom de Translat, té per objectiu la construcció d'una base de dades de traduccions literàries catalanes medievals fins a I500. Els resultats del projecte es presenten en un doble format: el Cens de Traduccions Catalanes Medievals (TCM), editat per Lluís Cabré i Montserrat Ferrer, i la base de dades Translat DB, que s'alimenta del cens, l'amplia amb altres dades i permet cerques complexes. Tant el cens com la base de dades, encara en procés d'elaboració, estan oberts a la consulta pública a l'adreça <http://www.translatdb.narpan.net/>. No cal justificar gaire un projecte com aquest: mai no s'havia emprès una catalogació sistemàtica que permetés fer-se càrrec de la dimensió del fenomen de la traducció al català medieval, i sobre la qual es poguessin emprendre estudis literaris i culturals fonamentats en una gran part del corpus total i en la precisió i la qualitat de les dades.

Existeixen projectes paral.lels, similars en els objectius i en la manera de presentar els resultats. A Itàlia, el projecte Studio, Archivio e Lessico dei Volgarizzamenti Italiani manté una base de dades de traduccions medievals que, fins ara, ha catalogat les traduccions meridionals (<http://www.salvit.org/>). A França, el projecte Transmédie ha produït els dos volums de Translations Médiévales (Turnhout, 20II), que cataloguen les traduccions a les llengües gal-lorromàniques. Comptem també amb projectes catalans que ens precedeixen i que, en part, s'interseccionen amb el nostre. El projecte Boscán (Universitat de Barcelona; <http://www.ub.edu/ boscan/>) és una base de dades de traduccions hispàniques d'obres italianes des dels orígens fins a 1939, i la Bibliografia de Textos Catalans Antics (Universitat de Barcelona, <http://bancroft.berkeley.edu/philobiblon/biteca_ca.html>) descriu tots els manuscrits i impresos que contenen textos medievals catalans; per la seva exhaustivitat en l'inventari de textos i testimonis tots dos projectes han estat un punt de referència obligat a l'hora d'establir el catàleg Translat.

A diferència de Boscán i Biteca, que parteixen del testimoni (manuscrit o imprès) com a unitat de catalogació, Translat parteix de l'obra. Així doncs, a l'arrel de cada fitxa hi ha l'obra original, de la qual es cataloguen successivament les traduccions al català, amb indicació de tots els testimonis manuscrits o impresos antics que han conservat cada una de les traduccions, a més de les edicions modernes i de la bibliografia. El resultat en xifres és un catàleg d'unes 290 traduccions corresponents a 220 obres originals. Des del punt de vista operatiu, el projecte ha desenrotllat alhora el disseny de la base de dades i l'elaboració del cens, que ha esdevingut prioritària fins a la seva fixació el 20I2. Aquest darrer té un doble valor: és enciclopèdic, en la mesura que recull i sistematitza dades procedents de la bibliografia i divulga coneixements sobre algunes obres originals de difusió complexa o massa poc estudiades; i és fruit de la investigació, necessària en un projecte que tre- 
balla amb una gran quantitat de textos inèdits, sovint no identificats - o mal identificats—, i amb dades no sempre fiables, que fan necessàris la recerca documental, l'examen dels testimonis i l'estudi de la transmissió de l'obra original. Per això tant les fitxes del cens com les de la base de dades, ampliades amb altres camps, combinen dues presentacions: d'una banda, les dades precises, segures i sistematitzables (autoria o atribució, llengua d'origen de la traducció, títol, datació, testimonis, edicions, bibliografia; a la base de dades s'hi afegeixen íncipit i èxplicit, dedicataris i promotors, presència de pròlegs o comentaris); de l'altra, comentaris que presenten o discuteixen problemes que afecten l'autoria, la datació, l'existència d'una o diverses versions, els accidents de transmissió o les discrepàncies en la bibliografia, i que aporten també informacions i dades suplementàries per dotar d'un context bàsic els textos poc coneguts o problemàtics. Cada fitxa, doncs, es pot llegir alhora com l'entrada d'un catàleg, com un breu estat de la qüestió i, en alguns casos, com un autèntic article de recerca — i per això la majoria de les entrades que contenen aportacions originals van signades pels autors.

Com que el projecte es concep com un instrument al servei de la història literària i cultural, no se n'ha limitat l'abast a les traduccions conservades: és un objectiu del projecte catalogar també les traduccions no conservades però testimoniades en la documentació, i encara les adaptacions de textos originalment en una altra llengua (és a dir, la traducció i reescriptura totals o parcials inconfessades quan depassen la categoria de la simple font). Traduccions perdudes i adaptacions han estat objecte dels corresponents censos, encara provisionals (inclouen, fins ara, 28 traduccions perdudes i prop d'una trentena d'adaptacions); un cop abocats a la base de dades, es podrà creuar facilment la informació de totes tres categories (traduccions, adaptacions, i traduccions perdudes) i es podrà obtenir un panorama molt més complet de la circulació catalana d'una obra determinada. N'és un bon exemple la Consolació de la Filosofia de Boeci. El cens i la base de dades ofereixen: (I) la traducció de Pere Saplana; (2) la revisió de (I) feta per Antoni Ginebreda; (3) la traducció perduda de Pere Borró; (4) les traduccions de (I) i (2) a altres llengües (castellà, llatí i hebreu); i (5) un comentari sobre l'adaptació de la Consolació en el Llibre de Fortuna i Prudència de Bernat Metge. Un cop la base de dades s'hagi completat, aquestes dades es podran creuar amb les dels censos de traduccions perdudes i d'adaptacions: en el primer hi trobarem que va existir una traducció catalana perduda de l'Elegia de Diversitate Fortunae d'Arrigo da Settimello, un text deutor de la Consolació, i, en el segon, que també l'Elegia va ser adaptada per Metge al Llibre de Fortuna i Prudència.

Aquest exemple il.lustra algunes qüestions de mètode $\mathrm{i}$ alguns problemes que planteja l'exposició sistemàtica de la relació entre testimonis i d'uns textos amb uns altres. La determinació del model del qual es tradueix implica també deter- 
minar-ne la llengua i presentar amb claredat el procés que porta de l'obra original a la traducció - $\mathrm{i}$, si és el cas, a traduccions a altres llengües. Això és important perquè un bon nombre de traduccions romàniques no deriven de l'original en llatí o en una altra llengua romànica, sinó d'una traducció intermediària. Això afecta sobretot títols llatins — traduïts a través d'una versió francesa, com ara Tit Livi o les Epistoles de Sèneca, o italiana, com Quint Curci-, però també textos romànics —és el cas d'obres franceses passades per una versió occitana. En la mateixa línia, convé observar que les traduccions catalanes poden ser la font de traduccions a altres llengües. En el cens, la transmissió d'una obra a través de la diversitat de llengües es mostra en un esquema eloqüent al principi de la fitxa; a la base de dades, les fitxes de cada text s'encadenen de manera jerarquitzada i ofereixen a primer cop d'ull un mapa de la relació de les traduccions catalanes amb les seves fonts i amb la seva descendència. Aquestes informacions, llegides en conjunt, es poden relacionar amb contextos històrics i culturals precisos i tenen transcendència per a l'estudi de les relacions culturals entre els regnes hispànics. No cal dir que hi ha molts casos en què la determinació de la llengua-font de la traducció, o la direcció que ha seguit el procés traductor, resta encara incerta sense la investigació a fons que molts textos demanen — i així es fa constar-, però és un resultat factual del projecte la definició d'aquestes relacions en més d'una obra, així com la identificació de nous casos de traducció a través del català. Per exemple, s'estableix la relació entre les versions castellana i catalana de la Scala Celi falsament atribuïda a sant Jeroni (72.3.I), o la de les versions de les epístoles apòcrifes de Lèntul i de Ponç Pilat (O.I4.I i O.I5.I), i s'identifiquen les versions castellanes de les traduccions catalanes de les Heroides d'Ovidi (92.2.I) o dels Viatges de Mandeville (7I.I.I).

La investigació de primera mà s'estén fins a la identificació de textos i d'originals, la fixació d'atribucions i el descobriment —o redescobriment - de traduccions ignorades. Per exemple, es posa ordre en una sèrie de textos atribuïts a sant Bernat: s'estableix que la Manera de Contemplar la Passió (I9.2.I) transmesa sense nom d'autor, i atribuïda a Bernat (Biteca), és en realitat un pseudo Beda, i s'identifiquen i unifiquen textos catalogats com a diferents a Biteca, així en el cas de la Passió de Jesucrist (22.3.I) i el Llibre de Meditació (22.4.I). Pel que fa a la identificació d'originals, s'aclareix que una de les tres versions de la Visió de Tnugdal (0.53.2) tradueix la redacció llatina del Speculum Historiale de Vicenç de Beauvais, o que la traducció del Liber de Vita et Moribus Philosophorum del pseudo Walter Burley (I24.I.I) deriva d'una versió italiana impresa que contenia fragments de la traducció llatina d'Ambrogio Traversari de les Vides dels Filòsofs de Diògenes Laerci. S'incorporen, també, traduccions fins ara no identificades, com l'Oikonomikos de Brison (I6.I.I), establerta fa poc per Jaume Riera, o se'n 
redescobreix una de negligida, no catalogada enlloc, del Llibre de les Revelacions de Constança de Rabastens (32bis.I), important perquè la versió catalana és l'únic testimoni conservat de l'obra (és semblant el cas de la traducció poc coneguda de la Visió de Louis d'Auxerre de Taddeo de' Gualandi (II6.I.I), que permet corregir l'únic testimoni conservat de l'original llatí). Aquestes poques mostres ben just expressen la feina que s'amaga rere el catàleg que ara s'ofereix amb la intenció de promoure la investigació en aquest camp d'estudi.

Un darrer problema a considerar és la multiplicitat de versions. Quan tenim testimonis catalans diversos d'una obra original, ens hem de plantejar si ens trobem davant traduccions diferents d'una obra textualment molt estable, de traduccions diferents d'un original conservat en redaccions diferents o amb molta variació textual, o de redaccions diferents d'una mateixa traducció. Malgrat que hi ha molts casos de doble traducció perfectament determinats i que no ofereixen problemes especials (als quals se n'aporten de nous, com una segona traducció del De Officiis de Ciceró (29.I.2)), la majoria respon a una casuística més complexa, sobretot en l'àmbit dels textos didàctics i morals de difusió àmplia. Entre els darrers, podem destacar el cas de la Somme le Roi francesa (8I.I): el cens recull les conclusions de la bibliografia, que pressuposa tres traduccions diferents procedents de dos originals diversos (original francès i una traducció occitana), però també recull el resultat d'una nova anàlisi de les dades, que apunta a una sola traducció amb una marcada variació textual entre els testimonis. Plantegen problemes semblants les fitxes sobre els Disticha Catonis (vegeu les observacions a 28.I.I i 28.I.2) o el De Cura et Modo Rei Familiaris Gubernandae atribuït a sant Bernat (vegeu 22.I.I).

En la fase actual del projecte s'està procedint a completar la base de dades amb les informacions que el cens no inclou i les que no poden ser transvasades de manera automàtica, amb la creació de fitxes relatives a les retraduccions del català a altres llengües i amb la incorporació de les traduccions perdudes i les adaptacions. Com s'ha dit, el cens complet (TCM) i Translat DB estan oberts a la consulta pública - i oberts, també, als suggeriments dels usuaris. Confiem que tots dos instruments mantindran la seva utilitat en el futur.

\section{REFERÈNCIES}

Ferrer, M., i Cabré, Ll., "Reflections on the Making of a Census of Medieval Catalan Translations", Digital Philology, en premsa.

Pujol, J., "Translat: una base de dades de traduccions literàries al català medieval (I300-I500)", Quaderns. Revista de Traducció, I5 (2008), pp. 213-22I. 